\title{
The effect of using some natural growth promoters on growth performance and feed utilization of monosex Nile tilapia (Oreochromis niloticus), fingerlings
}

\author{
Nabil F. Abdel-Hakim ${ }^{1}$; Ashraf M. A-S. Goda ${ }^{2}$; Mohamed E. Lashin ${ }^{1}$; \\ Al-Desoki A. Al-Azab ${ }^{1}$ and Hani M. Nazmi ${ }^{2}$ \\ 1- Department of Animal Production, Faculty of Agriculture, Al-Azhar University, Egypt \\ 2- Aquaculture Division, National Institute of Oceanography and Fisheries (NIOF), Egypt
}

\section{ABSTRACT}

An experimental study was conducted to evaluate the effect of three different natural growth promoters as feed additives on growth performance of monosex Nile tilapia fingerlings. Three nutritional treatments were applied at two additive levels ( $0.15 \& 0.3 \%)$ of Paprika (Hot Red Pepper "Capsicum annuum" meal), Proplis (Bee Glue) and Humapol-FIS Substance (Humic \& Fulvic acids with Mixture of Minerals) each one in addition to Control diet. The tested treatments were conducted in two cement ponds $(8 \times 4 \times 1 \mathrm{~m})$, divided with nets to 16 equal aquatic compartments $(2 \times 2 \times 1$ $\mathrm{m}) ; 14$ of them were used and stocked randomly with 20 fish/each one with an average initial body weight of $23.62 \pm 0.13 \mathrm{~g}$. The experiment lasted for 20 weeks (Six feeding days/week with the feeding rate at 3\% of live body weight/day). The results at the end of the experiment showed that, growth performance and feed conversion ratio were significantly $(\mathrm{P}<0.05)$ improved for monosex tilapia fingerlings fed on diets with the aforementioned natural feed additives compared to fish fed on the control diet. Feed cost required to produce $1 \mathrm{~kg}$ weight gain compared to fish fed on the control diet was reduced by using the feed additives. These results revealed that using Proplis $(\mathrm{P})$ at a dietary additive level of $0.3 \%$ was the best treatment in terms of growth performance and feed utilization, while the highest revenue and the best economic evaluation were obtained from the Paprika (K) diet at a level of $0.3 \%$ compared to the control diet.

Keywords: Growth promoters, feed additives, O. niloticus, growth performance, Proplis, Paprika, Humic substances.

\section{INTRODUCTION}

Aquaculture has evolved as the fastest growing food producing sector and developed as important component in food security (Ibrahem et al., 2010). Therefore, it is considered as the world worth coming expansion to compensate the shortage in animal protein. Feed in aquaculture plays an important role in the production cycle and exert threshold on both practical and economic aspects. Feed additive sectors are expanding day after day to achieve better growth and health for fish and shrimp and to meet the potential requirements of the culturists (Ibrahem, 2013).

In Egypt, the production of fish coming from aquaculture represents about $74 \%$ of total fish production sources (GAFRD, 2012). This activity requires high-quality feeds, which should contain not only necessary nutrients, but also complementary feed additives to keep organism's healthy, favor growth and environment-friendly aquaculture. Feed additives are substances which added in trace amounts provide a mechanism by which such dietary deficiencies can be addressed which benefits not only the nutrition and thus the growth rate of the animal concerned, but also its health and welfare in modern day fish farming (Eid and Khalid, 2008). There is a large number of feed additives available to improve fish growth performance but some of 
these additives used in feed mills are chemical products especially hormones and antibiotics which may cause unfavourable side effects (Baruah et al. 2008). Antibiotics have been used for many years as growth promoting agents in addition to their anti-pathogenic bacterial function which reduce growth and impaired feed conversion. These growth promoters were linked to emergence of multiple drug resistant bacteria and antibiotic residues in animal products (Wary and Davies, 2000). Thus, the use of antibiotic growth promoters (AGPs) as feed additives in the aquaculture industry has been criticized by government policies and consumers because of possible development of microbial resistance to these products and their potential harmful effects on human health (Baruah et al. 2008). To keep a sustainable growth pattern and health management, strategies must go beyond antibiotics and chemotherapeutics, which create resistant bacteria and immunosuppression in the host (Panigrahi and Azad, 2007; Adekunle, 2012). Therefore, using natural feed additives to substitute antibiotics has become an area of great interest (Kumar et al., 2003). World Health Organization encourages using of medicinal herbs and plants to substitute or minimize the use of chemicals through the global trend to go back to the nature. Attempts to use the natural materials such as medicinal plants could be widely accepted as feed additives to enhance efficiency of feed utilization and animal productive performance (Levic et al., 2008).

Some of the natural feed additives for animal feed are humic substances, which classified as a decomposed natural organic matter; they are composed of humus, humic acid, fulvic acids, ulmic acids, humin and minerals (Osman Tolga, 2012). Humic acid is the most common form of organic carbon in the natural environment. Most humic substances are chemically attached to inorganic components (clay minerals and oxides), and a smaller part gets dissolved in the soil (Islam et al., 2005). Humic acid is generally shown many positive effects on the fattening performance, resistance against diseases, immune system and stress in poultry production (Osman Tolga, 2012).

Red pepper (Capsicum annuum) Linn (family: Solanaceae) produces capsain and capsaicin, used as spice and medicine (Columbus, 1987). Capsaicin, the pungent active principle of red chilli has been shown to cause gastric mucosal oedema and hyperemia and decrease in the gastric acid output (Desai et al., 1977; Nopanitaya, 1973). Capsaicin helps the metabolism of epoxide aromatic hydrocarbons, which interferes with their ability of bind to DNA "causing mutations" (Suzuki and Iwai, 1984). Paprika and chilli contain a large amount of carotenoids, including capsanthin, capsorubin, b-carotene, cryptoxanthin, and zeaxanthin. The carotenoid concentrations encountered in paprika and chilli samples are 2.6 and $3.3 \mathrm{mg} / \mathrm{g}$ dry matter, respectively, according to Schweiggert et al. (2007). Another important carotenoid is capsaicin, responsible for the pungent characteristic of these products, which is only present in chilli peppers and has been shown to be effective against some bacteria and fungi (Cichewicz and Thorpe, 1996; Singh and Chittenden, 2008; Kraikruan et al., 2008; Tewksbury et al., 2008). However, chilli peppers, as well as paprika peppers, contain other components whose antimicrobial activities have not been well studied, as capsanthin or capsorubin. These two compounds, which are responsible for the red colour, can only be found in Capsicum products (Schweiggert et al., 2007).

Propolis (bee glue) is a natural dark-coloured and is used as a sealant and sterilant in their nests. Propolis has been used since ancient times as a medicine because of its biological properties as an antimicrobial, antifungal, antiprotozoan and antiviral agent (Krell, 1996). Propolis is a resinous sticky substance produced by honeybees. The bees collect it from trees, buds, flowers and other botanical sources and mixed with 
hypo pharyngeal secretions for protection of hives as sealer, draught excluder and embalming substance to cover arises from hive-invaders and against bacterial and fungal infection (Kosalec et al., 2003; Cuesta et al., 2005). Propolis has many different biological and pharmacological properties such as antibacterial, antifungal, antiviral, antiprotozoae, local-anesthetic, anti-inflammatory and immunostimulant (Miyake and Shibamoto, 1997; Sforcin, 2007). The most potent microbicidal componant in propolis is flavanone pinocembrin "5,7-dihydroxyflavanone" (Houghton et al., 1995). Propolis exhibits bacteriostatic activity against different bacterial genera and can be bactericidal at high concentrations (Drago et al., 2000).

The objective of this study, to investigate the effect of three different dietary natural feed additives (Humic substance, Paprika and Proplis) as growth promoters in Nile tilapia, fingerlings diets on growth performance, feed utilization, survival rate, whole body chemical composition and economic evaluation.

\section{MATERIALS AND METHODS}

\section{Experimental unit}

The present study was conducted on the Fish Research Station at El-Kanater El-khairia, National Institute of Oceanography and Fisheries (NIOF), Qalyubia Governorate, Egypt. Two cement ponds $(8 \times 4 \times 1 \mathrm{~m})$ were used; each pond was divided to equal eight aquatic compartments by nets with the total water volume of $4 \mathrm{~m}^{3}$ $(2 \times 2 \times 1 \mathrm{~m})$ each one; 14 of them were used and stocked with the experimental fish and supplied with fresh water from well with depth $60 \mathrm{~m}$ underground. The turnover rate of water was $20 \%$ daily/pond; fish were held under a natural light photoperiod at $12 \mathrm{~h}$ light/ $12 \mathrm{~h}$ dark schedule.

\section{Experimental fish}

Two hundred and eighty of mono sex Nile tilapia, Oreochromis niloticus (sex reversed with hormone treatment), were used in the present study. The fish were purchased and transported at early morning using a special fish transport car with aeration facilities from a private tilapia hatchery in El-Fayoum and were used in the experiment after acclimatization to the experimental system under normal conditions for seven days before starting the experiment. Thereafter, the fish were randomly divided into equal experimental groups $(40$ fish each Level/treatment; 2 replicate/level) representing four nutritional groups. One group served as control diet and three groups were represented the feed additives tested. The experimental fish were weighted every 4 weeks in order to adjust the daily feed rate, which was $3 \%$ of the average fish body weight. The daily ration of feed was divided into two equal amounts and offered at two times/ day $(9.00$ am and $3.30 \mathrm{pm})$ for six feeding days per week. The initial weight of experimental fish was stocked with an average body weight of $23.62 \pm 0.13 \mathrm{~g}$, at a stocking density of $5 \mathrm{fish} / \mathrm{m}^{3}$. The experiment lasted for 20 weeks after the start.

\section{Experimental diets}

Seven isonitrogenous diets were formulated to contain (25\%, Crude Protein) and isocaloric $(4400 \mathrm{Kcal}$ gross energy $/ \mathrm{kg}$ diet) from practical ingredients (Table1) including the control basal diet (without feed additives). The other diets were supplemented by three different sources of natural growth promoters at two dietary additive levels (0.15 and $0.3 \%$ ) of each Paprika, K (Hot Red Pepper meal), Proplis, P (Bee Glue) and Humapol-FIS Substance, H (Humic \& Fulvic acids with Mixture of Minerals). The experimental diets were prepared by individually weighing of each component and by thoroughly mixing the mineral, vitamins and additives. This 
mixture was added to the components together with oil. Water was added until the mixture became suitable for making granules. The wet mixture was passed through a granule machine with the $2 \mathrm{~mm}$ diameter. The produced pellets were sun-dried for (48 h) and kept frozen at $\left(-4^{\circ} \mathrm{c}\right)$ until the experimental start and used.

Table 1: Composition and proximate analysis of the experimental diets

\begin{tabular}{|c|c|c|c|c|c|c|c|}
\hline \multirow[t]{3}{*}{ Feed Ingredients } & \multicolumn{7}{|c|}{ Experimental Diets } \\
\hline & \multirow{2}{*}{ Control } & \multicolumn{2}{|l|}{$\mathbf{H}$} & \multicolumn{2}{|l|}{$\mathbf{K}$} & \multicolumn{2}{|l|}{$\mathbf{P}$} \\
\hline & & 0.15 & 0.3 & 0.15 & 0.3 & 0.15 & 0.3 \\
\hline Fish meal (59.9\%) & 12.00 & 12.00 & 12.00 & 12.00 & 12.00 & 12.00 & 12.00 \\
\hline Soybean meal (44\%) & 26.00 & 26.00 & 26.00 & 26.00 & 26.00 & 26.00 & 26.00 \\
\hline Yellow corn & 37.35 & 37.20 & 37.05 & 37.20 & 37.05 & 37.20 & 37.05 \\
\hline Wheat bran & 20.00 & 20.00 & 20.00 & 20.00 & 20.00 & 20.00 & 20.00 \\
\hline Sun flower oil & 2.00 & 2.00 & 2.00 & 2.00 & 2.00 & 2.00 & 2.00 \\
\hline Fish premix $^{1}$ & 1.50 & 1.50 & 1.50 & 1.50 & 1.50 & 1.50 & 1.50 \\
\hline Di-Calcium Phosphate & 1.00 & 1.00 & 1.00 & 1.00 & 1.00 & 1.00 & 1.00 \\
\hline Lysine & 0.05 & 0.05 & 0.05 & 0.05 & 0.05 & 0.05 & 0.05 \\
\hline Methionine & 0.10 & 0.10 & 0.10 & 0.10 & 0.10 & 0.10 & 0.10 \\
\hline Humapol-FIS $^{2}$ & & 0.15 & 0.30 & & & & \\
\hline Paprika $^{3}$ & & & & 0.15 & 0.30 & & \\
\hline Proplis ${ }^{4}$ & & & & & & 0.15 & 0.30 \\
\hline Total & 100 & 100 & 100 & 100 & 100 & 100 & 100 \\
\hline \multicolumn{8}{|c|}{ Chemical analysis of the experimental diets (on DM basis) } \\
\hline Dry matter $\%$ & 88.74 & 88.97 & 89.00 & 88.85 & 88.92 & 88.70 & 88.58 \\
\hline Crude protein $\%$ & 25.18 & 25.19 & 25.23 & 25.20 & 25.26 & 25.25 & 25.34 \\
\hline Ether extract \% & 5.03 & 5.00 & 5.08 & 5.11 & 5.17 & 5.20 & 5.29 \\
\hline Crude fiber $\%$ & 4.82 & 4.84 & 4.90 & 4.88 & 4.94 & 4.81 & 4.85 \\
\hline Ash \% & 6.64 & 6.75 & 6.91 & 6.69 & 6.85 & 6.83 & 6.90 \\
\hline N.F.E ${ }^{5}$ & 58.33 & 58.22 & 57.88 & 58.12 & 57.78 & 57.91 & 57.62 \\
\hline Gross energy $(\mathrm{Kcal} / \mathrm{kg})^{6}$ & 4424.01 & 4418.14 & 4416.76 & 4426.70 & 4424.56 & 4426.83 & 4430.42 \\
\hline $\begin{array}{l}* \mathrm{H}, \mathrm{K} \text { and } \mathrm{P} \text { are symbo } \\
\text { 1- Each kg of vitamins } 8 \\
60 \mathrm{mg} \text {; KI, } 0.4 \mathrm{mg} \text {; CuS } \\
\text { ferric citrate, } 250 \mathrm{~m} \\
\text { tocopherolacetate, } 400 \mathrm{~m} \\
\text { thiamine, } 30 \mathrm{mg} \text {; rib } \\
\text { acid, } 10 \mathrm{mg} \text {; biotin, } 3 \mathrm{mg} \\
\text { acid, } 100 \mathrm{mg} \text {; inosito } \\
\text { 2- Each kg of HUM } \\
\text { Manufactured by VITAI } \\
\text { POLLEN FEED AD } \\
\text { Ballkesir - Turkey } \\
\text { 3- Each of } 100 \mathrm{~g} / \mathrm{kg} \text { Par } \\
\text { Crude fiber, 7.99\%; Ash } \\
\text { N.F.E } \text {, 60.48\%. } \\
\text { 4- Each 100g of Egyptia } \\
\text { (2.4\%); dihydrochalcone } \\
\text { (6.5\%); Chalcones (1.7 } \\
\text { Hady and Higazi (2002) } \\
\text { 5- Nitrogen free extract } \\
\text { 6- Gross energy Calcula } \\
\text { Jobling (1983) }\end{array}$ & $\begin{array}{l}\text { ed to diets co } \\
\text { nineral mixt } \\
12 \mathrm{mg} \text {; } \\
\text { Na2SeO3, } \\
\text { menadione, } \\
\text { avin, } 40 \mathrm{mg} \\
\text { pantothenic } \\
00 \mathrm{mg} \text {; asco } \\
\text { Ol-FIS }{ }^{\circledR} \text { co } \\
\mathrm{N} \\
\text { TIVES. SAI } \\
\text { ka meal con } \\
.95 \% \text {; } \\
\text { Propolis con } \\
\text {; flavanones } \\
\text { FE) = } 100- \\
\text { Based on } 5\end{array}$ & $\begin{array}{l}\text { taining } \mathrm{Hu} \\
\text { e premix cc } \\
24 \mathrm{mg} \text {; C } \\
2 \mathrm{mg} ; \\
\text { pyridoxine, } \\
\text { jic acid, } 50 \\
\text { tained: Hu } \\
\text { TIC. LTD. } \\
\text { ained: Dry } \\
\text { ains: pheno } \\
1.9 \% \text { ); flav } \\
\text { CP + EE + } \\
55 \mathrm{Kcal} / \mathrm{g} \mathrm{p}\end{array}$ & $\begin{array}{l}\text { apol-FIS, } \\
\text { tained: } \mathrm{Mn} \\
0.2 \mathrm{mg} \text {; } \\
0 \mathrm{mg} \text {; cyan } \\
\text { ng. } \\
\text { ic acid } 70 \\
\text { TI. Establi } \\
\text { atter, } 87.43 \\
\text { acid ester } \\
\text { nes (4.6\%) } \\
\text { h). }\end{array}$ & $\begin{array}{l}\text { prika and } \mathrm{P} \\
\text { 44, } 40 \mathrm{mg} \text {; } \\
\text { inol, 40,00 } \\
\text { cobalamin, } \\
\text {, Fulvic } \\
\text { ed since } 1 \\
\text { Crude prot } \\
\text { (72.7\%); ph } \\
\text { nd tetrahyd }\end{array}$ & $\begin{array}{l}\text { plis, respec } \\
\text { IgO, } 10 \mathrm{mg} \\
\text { IU; cholec } \\
0 \mathrm{mcg} \text {; nico } \\
\text { id } 180 \mathrm{~g} \text {, } \\
\text { in, Agir Sa } 17.54 \% \text {; } \\
\text { nolic acids } \\
\text { furan deriv }\end{array}$ & $\begin{array}{l}\text { ely. } \\
\text { ciferol, } 4,0 \\
\text { nic acid, } 30 \\
\text { neral mixt } \\
\text { Bölge Ke } \\
\text { ther extrac } \\
.1 \%) \text {; aliph } \\
\text { tives ( } 0.7 \%\end{array}$ & $\begin{array}{l}\text { ZnCO3, } \\
\mathrm{IU} ; \alpha- \\
\mathrm{mg} \text {; folic } \\
120 \mathrm{~g} \text {; } \\
\text { sut Cd., } \\
4.04 \% \text {; } \\
\text { ic acids } \\
\text { Abd El } \\
\text { rding to }\end{array}$ \\
\hline
\end{tabular}

\section{Sampling and Experimental Methodology}

At the beginning of the experimental trial, four pooled groups of Nile tilapia fish were collected to serve as an initial carcass composition. At the end of the experiment, 4 fish from each aquatic compartment were sampled at random from each level/treatment. The tested diets and fish samples were analyzed for crude protein (CP $\%)$, ether extract (EE \%), crude fiber ( $\mathrm{CF} \%$ ), ash (\%) and moisture, while the whole 
body composition of fish samples were taken randomly and analyzed at the trial start and end, except crude fiber (CF \%) according to the procedures described by Standard Methods (1995). The nitrogen free-extract (NFE \%) was calculated by differences. Also, all calculations were based on dry matter weight.

\section{Measurements of water quality parameters:}

Analytical methods of water quality were determined according to the American Public Health Association (APHA, 1998). Water temperature, dissolved oxygen, ammonia and $\mathrm{pH}$ were monitored during the experimental period to maintain water quality at the optimum range for Nile tilapia. Water temperature was recorded daily in each pond using a mercury thermometer $\left({ }^{\circ} \mathrm{C}\right)$ suspended at $30 \mathrm{~cm}$ water depth, dissolved oxygen was measured by a digital oxygen meter (Yellow Spring Instrument Co., model 58, OH, USA); total ammonia was measured using DREL/2 HACH kits (HACH Co., Loveland, CO, USA) and $\mathrm{pH}$ values were determined by a digital $\mathrm{pH}-$ meter (Digital Mini-pH Meter, model 55, Fisher Scientific, Waltham, MA, USA).

\section{Growth performance records maintained}

Live body weight and body length

Live body weight (LBW), g and body length (BL), cm of individual fish of each experimental aquatic compartment were recorded every 4 weeks during the experimental period.

The average weight-gain (AWG), specific growth rate (SGR), feed conversion ratio (FCR), feed efficiency ratio (FER) and Survival rate (SR) were calculated according to the following equations:

TWG $(\mathrm{g} /$ fish $)=$ final weight - initial weight.

$\operatorname{ADG}(\mathrm{g} /$ fish/d) $=$ total weight gain $(\mathrm{g}) /$ period (day)

RGR $(\%)=$ Total weight gain $(\mathrm{g}) /$ Initial weight $(\mathrm{g})$ X 100

$\mathrm{K}=\mathrm{W} /(\mathrm{L})^{3} \mathrm{X} 100$

Where: $\mathrm{W}=$ fish weight "grams"

$\mathrm{L}=$ fish length "cm"

$\mathrm{SGR}=\mathrm{LnW}_{2}-\mathrm{LnW}_{1} / \mathrm{T}$ X 100

Where: $\mathrm{Ln}=$ the natural $\log$

$\mathrm{W}_{2}=$ final weight at certain period $(\mathrm{g})$

$\mathrm{W}_{1}=$ Initial weight in the same period $(\mathrm{g})$

$\mathrm{T}=$ period of experiment (day).

SR $(\%)=$ No. of surviving fish/total No. of fish at the beginning X100

\section{Economic efficiency}

$\mathrm{EE}=$ Total income (L.E.) / Total costs (L.E.) X 100

\section{Statistical analysis}

Statistical analysis was performed using analysis of variance (ANOVA). It was performed with SPSS statistical software (version 17.0, SPSS). The data were subjected for test of homogeneity of variances and Duncan post-hoc test. Duncan's multiple range test (Duncan, 1955) was used to resolve differences among treatment means at 5\% significance level (Data were considered significantly different when $\mathrm{P}<$ $0.05)$.

\section{RESULTS AND DISCUSSION}

\section{Quality parameters of rearing water}

All tested water quality criteria were suitable for rearing Nile tilapia fingerlings as cited by El-Hammady (2001), Abdel-Hakim et al. (2002) and Abdelhamid (2009). The water temperature ranged between $\left(27\right.$ and $\left.28^{\circ} \mathrm{C}\right), \mathrm{pH}$ values $(7.5$ and 9$)$, and 
dissolved oxygen ranged between ( 7 and $8.5 \mathrm{mg} / \mathrm{l})$. Also, Abdelhamid et al. (2002) suggested that these values are suitable for rearing Nile tilapia. In the same trend, Abdelhamid et al. 2004) found that all the tested water quality (temperature, $\mathrm{pH}$ value, conductivity $\mathrm{mg} / \mathrm{l}$ and dissolved oxygen $\mathrm{mg} / \mathrm{l}$ ) criteria were suitable for rearing Nile tilapia fish.

\section{Growth performance and Feed Utilization}

In general, the fish growth experiment performed very well with growth and feed efficiency similar or higher than the control diet. The growth performance parameters of Nile tilapia (Oreochromis niloticus) fingerlings which fed diets supplemented with other feed additives of Paprika, Proplis and Humapol-FIS are shown in Table (2). Average of initial body weight of Nile tilapia fingerlings fed on the experimental diets at the start was not different, indicating that the groups were homogenous.

Table 2: Growth Performance and feed utilization of Nile tilapia fingerlings fed on the experimental diets

\begin{tabular}{lcccccccc}
\hline \multirow{2}{*}{ Parameters } & \multicolumn{7}{c}{ Experimental Diets } \\
\cline { 2 - 9 } & Control & H 0.15 & H 0.3 & K 0.15 & K 0.3 & P 0.15 & P 0.3 & \pm SE* \\
\hline Initial avg. wt. (g) & 23.67 & 23.52 & 23.58 & 23.60 & 23.55 & 23.69 & 23.74 & 0.13 \\
Final avg. wt. (g) & $172.85^{\mathrm{c}}$ & $175.24^{\mathrm{c}}$ & $178.92^{\mathrm{c}}$ & $187.73^{\mathrm{b}}$ & $191.51^{\mathrm{b}}$ & $194.30^{\mathrm{ab}}$ & $200.16^{\mathrm{a}}$ & 1.36 \\
Weight gain (g) $^{176.42}$ & 170.61 & 167.96 & 164.13 & 155.34 & 151.72 & 149.18 & 1.27 \\
SGR (\%/day) & $1.42^{\mathrm{c}}$ & $1.43^{\mathrm{c}}$ & $1.45^{\mathrm{bc}}$ & $1.48^{\mathrm{ab}}$ & $1.50^{\mathrm{ab}}$ & $1.50^{\mathrm{ab}}$ & $1.52^{\mathrm{a}}$ & 0.01 \\
RGR (\%) & $630.25^{\mathrm{c}}$ & $645.07^{\mathrm{c}}$ & $658.78^{\mathrm{c}}$ & $695.47^{\mathrm{b}}$ & $713.21^{\mathrm{ab}}$ & $720.18^{\mathrm{ab}}$ & $743.13^{\mathrm{a}}$ & 3.61 \\
FCR & $1.48^{\mathrm{c}}$ & $1.48^{\mathrm{c}}$ & $1.46^{\mathrm{b}}$ & $1.42^{\mathrm{ab}}$ & $1.40^{\mathrm{a}}$ & $1.39^{\mathrm{a}}$ & $1.38^{\mathrm{a}}$ & 0.01 \\
PER & $2.68^{\mathrm{c}}$ & $2.69^{\mathrm{bc}}$ & $2.71^{\mathrm{c}}$ & $2.79^{\mathrm{b}}$ & $2.82^{\mathrm{ab}}$ & $2.84^{\mathrm{ab}}$ & $2.87^{\mathrm{a}}$ & 0.02 \\
Feed intake (g) & 242.83 & 237.87 & 235.57 & 233.13 & 227.33 & 224.29 & 221.36 & 1.66 \\
Survival rate (\%) & 100 & 95 & 97.5 & 100 & 100 & 100 & 100 & 0.94 \\
\hline
\end{tabular}

* Values are presented as means \pm standard error (SE). Means in the same row with different superscripts are significantly different $(\mathrm{P} \leq 0.05)$.

* H, K and P are symbolized to diets containing Humapol-FIS, Paprika and Proplis, respectively, followed by experimental additive levels of each one.

* Pooled standard error of a mean.

At the end of the experimental period (140 days), the group of fish fed on the supplemented diets grew as well or better than the group of fish fed on the control diet. Whereas, the final body weight of the fish groups fed on diets P0.3, P0.15 and K0.3 had significantly $(\mathrm{P}<0.05)$ higher body weight than the rest of the experimental groups. However, the lowest final body weight (172.85 g) was achieved by the group of fish fed on the control diet. Analysis of variance for weight gain followed the same trend as in the final body weights. On the other hand, the fish groups fed on diets $\mathrm{P} 0.3, \mathrm{P} 0.15$ and K0.3 had significantly $(\mathrm{P}<0.05)$ higher SGR than the rest of experimental groups. However, at the end of the trial, SGR values were 1.42 (control diet), $1.43,1.45,1.48,1.50,1.50$ and $1.52 \% / \mathrm{d}$ for fish groups fed on diets containing 0.15, 0.3 Humapol, Paprika and Proplis, respectively. The average values of the feed conversion ratio (FCR) in fish groups fed on diets $\mathrm{P} 0.3$ and $\mathrm{P} 0.15$ followed by groups of fish fed on diets $\mathrm{K} 0.3, \mathrm{~K} 0.15, \mathrm{H} 0.3$ and $\mathrm{H} 0.15$ were significantly $(\mathrm{P}<0.05)$ improved in comparison with the other groups and better than the basal diet. The FCR was found to be 1.48 (control diet), 1.38, 1.39, 1.40, 1.42, 1.46 and 1.48, respectively. These results indicated that the best $(\mathrm{P}<0.05)$ FCR values were obtained for a group of fish fed on diet P0.3, P0.15 and K0.3 respectively. The best FCR values observed with Proplis 0.3 supplemented diets suggested that addition of Proplis improved feed utilization. In practical terms, this means that the use of Proplis can decrease the amount of feed necessary for animal growth, which could result in reductions of 
production cost. The same trend was observed in PER where the fish groups fed on diets $\mathrm{P} 0.3$ and $\mathrm{P} 0.15$ showed better $(\mathrm{P}<0.05)$ PER values compared with the other groups. The PER was found to be 2.68 (control diet), 2.69, 2.71, 2.79, 2.82, 2.84 and 2.87 for groups of fish fed diets H0.15, H0.3, K0.15, K0.3, P0.15 and P0.3, respectively. The protein efficiency ratio results indicated that supplementing diets with Proplis was significantly $(\mathrm{P}<0.05)$ improved protein utilization in the diets of tilapia. Also, in the present study, the natural growth promoters were used had significantly $(\mathrm{P}<0.05)$ enhanced feed efficiency. These results are in agreement with the results of Abd-El-Rhman (2009) who fed Nile tilapia fingerlings by Proplis as supplementation in fish diet and reported that, the greater growth performance than those fed on the control diet. Also, reported that the diet contained 30\% protein as basal diet supplemented with Propolis-ethanolic-extract (1\%) and crude propolis (1\%) produced the highest growth rate, average daily gain (ADG), specific growth rate (SGR) and feed efficiency ratio (FER) among O. niloticus. On the other hand, the best feed conversion ratio (FCR) was obtained with propolis-ethanolic-extract, but Alberto Cuesta et al. (2005) found little effect of propolis on gilthead seabream growth, fed for up to six weeks. Also, they found that the specific growth rate was not significantly affected by the dietary intake of propolis at 0.1 and $10 \mathrm{~g}$ propolis $\mathrm{kg}$ diet, moreover Proplis is an appropriate growth-stimulating additive in tilapia cultivation. It is also necessary, to consider the possibility of interspecies differences with the use of the Proplis. In addition, the supplementation of Proplis led to $100 \%$ Survival rate, which is shown in Table (2). These results about Survival rate are in agreement with Guobin Zhang et al. (2009) who were feeding Chinese sucker fish with different dosage $(0.1 \%, 0.5 \%$ or $1.0 \%)$ of traditional Chinese medicine (TCM) formulated from propolis and Herba Epimedii extracts at the ratio of 3:1 $(\mathrm{w} / \mathrm{w})$ extracts for five weeks and recorded that, feed containing $0.5 \%$ TCM extracts was the most effective with the mortality of the fish significantly reduced by $35 \%$ compared to the control. Also, Abd-El-Rhman (2009) found the fish mortalities kept decreasing compared with the control diet. The same trend results were observed by Turan (2006) who used the medical herb red clover (Trifolium Pretense) as a growth-promoting agent for tilapia, O. aureus. Zakes et al. (2008) also reported that juvenile pike perch (Sander lucioperca) fed on diets supplemented by medicinal plants exhibited faster growth than those fed on the control diet. Similar results were reported for using medicinal plants as growth-promoting agents for the common carp, Cyprinus Carpio (Yilmaz et al. 2006). Also, Sevdan Yilmaz et al. (2013) supplemented diets for tilapia, Oreochromis mossambicus with astaxanthin, paprika and capsicum to determine their effects on growth performance and pigmentation and these found the growth performance was significantly improved in the paprika groups and recorded the best final weight, weight gain, SGR, and FCR were obtained with the $60 \mathrm{mg}$ paprika diet. In contrary with these findings, Wassef et al. (2010) fed Gilthead Seabream fish on the experimental diets contained red bell-pepper (Capsicum annum) meal and carrot (Daucus carota) meal as a natural dietary carotenoid source as compared to initial fish and detected no significant differences $(\mathrm{P}>0.05)$ in final weight or feed conversion ratio among fish fed on different carotenoid-added diets.

\section{Body composition}

Data of chemical composition (\% DM basis) of the fish body at the start and at the end of the experimental period are presented in Table (3) for those fed on the experimental diets. This Table explored that the average of the whole body composition, including crude protein (CP), ether extracts (EE) and ash, besides the energy content (GE) estimated as a dry matter basis. 
The carcass composition concerning their DM and EE contents are increased by age advance, but the ash percentages were decreased.

At the end of the experiment, percentages of the whole body DM, CP and ash were significantly $(\mathrm{P}<0.05)$ influenced by all dietary treatments. Otherwise, no Statistical differences were observed in the whole body ether extracts and gross energy. These results are in close agreement with the findings of Salem (2010), Ringo and Gatesoupe (1998) and Scholz et al. (1999). Nevertheless, Wassef et al. (2010) detected no considerable $(\mathrm{P}>0.05)$ differences in major nutrients composition between Gilthead Seabream fish fed on the experimental diets contained red bell-pepper (Capsicum annum) meal as a natural dietary carotenoid source as compared to initial fish. Also, Diab et al. (2002), Lara-Flores et al. (2003) and EL-Haroun et al. (2006), Eid and Khalid (2008) found that no differences were observed for moisture, ash and protein content among different dietary diets.

Table 3: Chemical composition of whole body Nile tilapia fingerlings fed on the experimental diets (As Dry Matter basis)

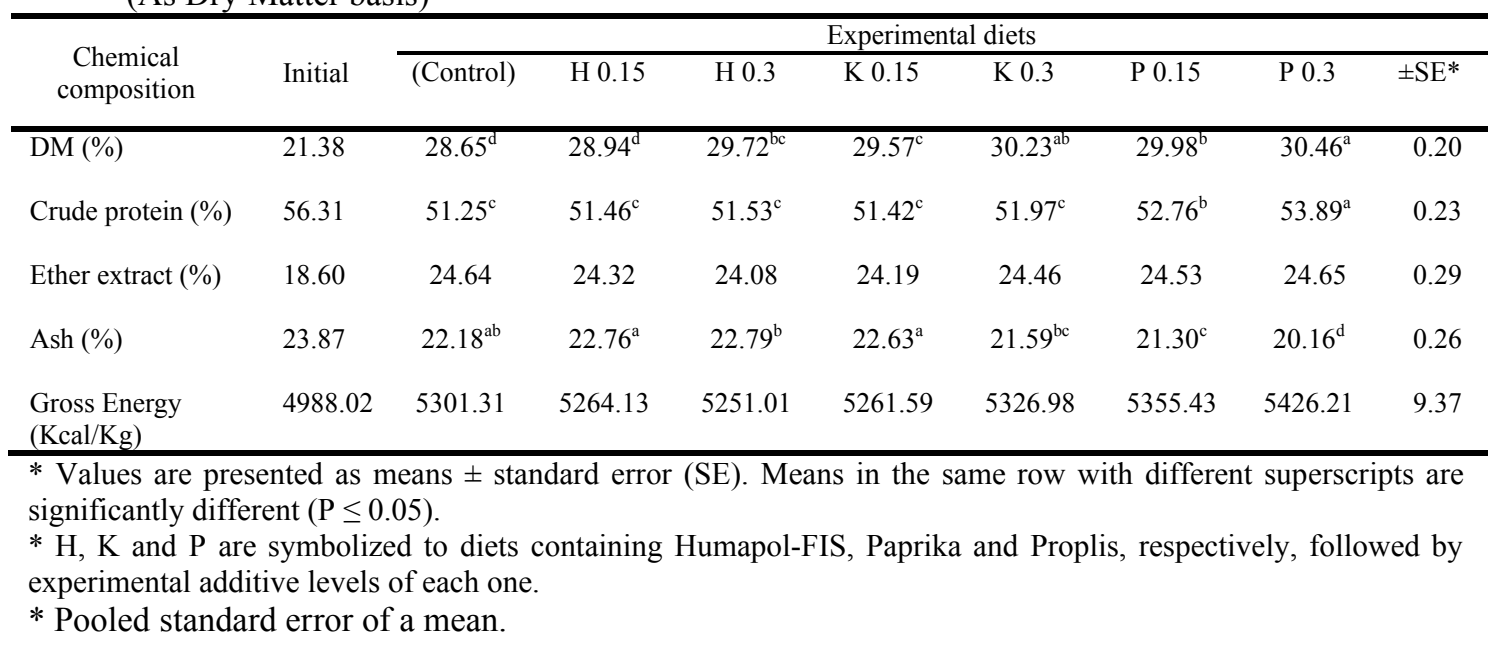

\section{Economic evaluation}

Results of inputs and outputs of the experimental treatments are present in Table (4). Calculations of economical efficiency of the tested diets based on the cost of the feed, the cost of one $\mathrm{kg}$ gain in weight and its ratio of the control group are shown in this table. Also, prices of experimental diets based on feed ingredients in the local market during the experiment are present in below of the Table.

As described in this Table Revenues (L.E) were the highest for the Paprika 0.30 diet (41.98 L.E) and gradually decreased with the decreasing addition level of it. This trend was found in tested feed additives were used. The lowest relative percentage of feed cost/ $\mathrm{kg}$ fish for improving growth and feed utilization parameters of mono sex Nile tilapia fingerlings as noted in Table (2). On the other hand, the incorporation of Paprika in tilapia fingerlings diets seemed to be economical at incorporation level $0.3 \%$. The reduction of feed costs was easily observed for the feed cost $/ \mathrm{Kg}$ weight gain, which decreased with increasing incorporation levels of Paprika as feed additives for tilapia fingerlings diets in agreement with EL-Haroun et al. (2006) who recorded the lowest values of total pond income (LE) and net production per pond for fish fed on the control diet $\left(4.72 \mathrm{~kg} \mathrm{pond}^{-1}\right)$ in comparison with fish fed on diet contents Biogens as feed additives at levels of $0.5 \%, 1.0 \%, 1.5 \%$ and $2.0 \%$ respectively.

Table 4: The economical efficiency of the experimental diets to produce one Kg gain of Nile tilapia. 


\begin{tabular}{|c|c|c|c|c|c|c|c|}
\hline \multirow[t]{2}{*}{ ITEMS } & \multirow[t]{2}{*}{ (control) } & \multicolumn{6}{|c|}{ Experimental Diets } \\
\hline & & H 0.15 & H 0.3 & K 0.15 & K 0.3 & P 0.15 & P 0.3 \\
\hline Initial weight $(\mathrm{Kg})$ & 0.947 & 0.941 & 0.943 & 0.944 & 0.942 & 0.948 & 0.950 \\
\hline Final weight $(\mathrm{Kg})$ & 6.914 & 7.010 & 7.157 & 7.509 & 7.660 & 7.772 & 8.006 \\
\hline Total amount of feed intake per treatment $(\mathrm{Kg})$ & 8.855 & 8.971 & 9.093 & 9.325 & 9.423 & 9.515 & 9.713 \\
\hline Price of one $\mathrm{kg}$ of ration (L.E.) & 3.47 & 3.50 & 3.52 & 3.51 & 3.54 & 3.70 & 3.92 \\
\hline Total feed costs (L.E.) & 30.73 & 31.40 & 32.01 & 32.73 & 33.36 & 35.20 & 38.08 \\
\hline Cost of the fingerlings per treatment (L.E) & 12.00 & 12.00 & 12.00 & 12.00 & 12.00 & 12.00 & 12.00 \\
\hline Total costs (L.E) & 42.73 & 43.40 & 44.01 & 44.73 & 45.36 & 47.20 & 50.08 \\
\hline Total fish weight gain per treatment $(\mathrm{Kg})$ & 5.967 & 6.069 & 6.214 & 6.565 & 6.718 & 6.824 & 7.057 \\
\hline Sale price Kg fish (L.E) & 13.00 & 13.00 & 13.00 & 13.00 & 13.00 & 13.00 & 13.00 \\
\hline Total income per treatment for fish weight gain (L.E) & 77.57 & 78.89 & 80.78 & 85.35 & 87.34 & 88.72 & 91.74 \\
\hline Revenues (L.E) & 34.85 & 35.49 & 36.77 & 40.62 & 41.98 & 41.51 & 41.66 \\
\hline Economic efficiency $(\%)$ & 181.56 & 181.78 & 183.55 & 190.80 & 192.56 & 187.94 & 183.20 \\
\hline \multicolumn{8}{|c|}{ 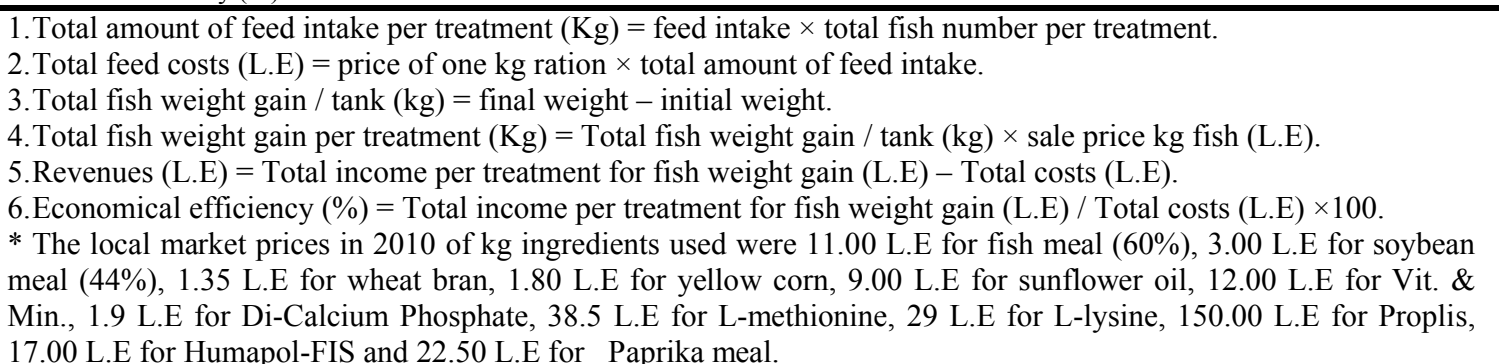 } \\
\hline
\end{tabular}

These results also indicated that, the highest economical efficiency was reported by the K0.3 group followed in a decreasing order by K0.15, P0.15, H0.3, P0.3, H0.15 and control group, respectively. These results indicated that, these feed additives can be incorporated in tilapia diets as the best natural growth promoter for better economical efficiency results as well as best growth performance and nutrient utilization. In this connection, Salem (2010) showed a lower cost of one ton of all diets containing probiotic. However, the control diet recorded the highest price, being 2916.2 LE/ton. The diets containing $(0.1 \%, 0.2 \%$, and $0.3 \%$ Bio-Nutra200) showed the low cost of fish diet comparing with the control diet. Yet, diets no. 1 and 4 showed high cost $/ \mathrm{kg}$ gain, being 6.86 and 5.32 LE, but diet no. 2 and 3 gave the lowest feed cost $/ \mathrm{kg}$ gain, being 4.70 and $4.57 \mathrm{LE}$. These results supported the results of Eid and Khalid (2008).

\section{CONCLUSION}

From the previous results, it could be concluded that the positive influence of additions (Proplis, Paprika meal and humapol-FIS) on growth performance of the monosex fingerlings, Nile tilapia diets showed positive effects and they are promising natural growth promoters as feed additives to fish diets. From feed utilization data and the economical point of view, the diets supplemented with Paprika $0.3 \%$ and Proplis $0.15 \%$ were the best treatments in comparison with Control diet.

\section{REFERENCES}

A.O.A.C. (1995). Association of Official Analytical Chemists, Official methods of analysis. 16th edition, AOAC, Arlington, Virginia, USA.

Abd El Hady, FK. and Hegazi, AG. (2002). Egyptian propolis, Chemical composition, antiviral and antimicrobial activities of East Nile Delta propolis. Z Naturforsch, 57c: 386-394.

Abdel-Hakim, N.F.; Bakeer, M.N. and Soltan, M.A. (2002). Water Environment for fish Culture. Deposition No.4774, ISBN: 977-298-228-5. 
Abdelhamid, A.M.; Khalil, F.F.; El-Barbary, M.I.; Zaki, V.H. and Hussein, H.S. (2002). Feeding Nile tilapia on Biogen to detoxify aflatoxin diets. Proc. 1st Conf. Animal \& Fish prod., Mansoura, 24\&25, Sep., 207-230.

Abdelhamid, A.M.; Mehrem, A.I.; El-Barbary, M.I.; Ibrahim, S.M. and Abdel-Wahab, A.I. (2009).Evaluation of a new Egyptian propiotic by African catfish fingerlings. J. of Enviro. Sci. and Technol., 2(2): 133-145.

Abdelhamid, A.M. (2009). Fundamentals of Fish Production and Aquaculture. New Academic Office, Alex. Deposition No.24400, ISBN: 977-438-052-5.

Abdelhamid, A.M.; Salem, M.F.I. and Tolan, A.E.(2004). Evaluation of sesame meal as a dietary protein source for Nile tilapia (Oreochromis niloticus) fingerlings. J. Agric. Sci. Mansoura Univ., 29:6887-6897.

Abd-El-Rhman, A. M. M. (2009). Antagonism of Aeromonas hydrophila by propolis and its effect on the performance of Nile tilapia, Oreochromis niloticus. Fish \& Shellfish Immunol., 27: 454 - 459.

Adekunle Ayokanmi DADA (2002). Effects of herbal growth promoter feed additive in fish meal on the performance of Nile Tilapia (Oreochromis niloticus (L.)). Egypt. Acad. J. Biolog. Sci., 4(1): 111-117.

Alberto Cuesta; Alejandro Rodri'guez, M. A Ngeles Esteban and Jose' Meseguer (2005). In vivo effects of propolis, a honeybee product, on Gilthead seabream innate immune responses. Fish \& Shellfish Immunol., 18: 71-80.

APHA. (1998). American Public Health Association, Standard methods for examination of water and wastewater, 20th edition. APHA, AWWA. Washington, DC., USA.

Baruah K.; Norouzitallab P.; Debnath D.; Pal A .K. and Sahu N.P. (2008). Organic acids as non-antibiotic nutraceuticals in fish and prawn feed. Aquacult. Health Internat., 12:4-6.

Cichewicz, R.H. and Thorpe, P.A. (1996). The antimicrobial properties of chile peppers (Capsicum species) and their uses in Mayan medicine J. Ethnophar., 52: 61-70.

Columbus LF (1987). Capsicum and capsaicin: past, present and future. Acta Physiol. Hung., 69: 265-273.

Cuesta A.; Rodrı A.; Esteban MA.; Meseguer J. (2005). In vivo effects of propolis, a honeybee product, on gilthead seabream innate immune responses. Fish \& Shellfish Immunol., 18:71-80.

Desai HG; Venugopalan K; Philipose M; Zaveri MP; Kalro RH and Antia FP (1977). Effect of red chilli powder on gastric mucosal barrier and secretion. Ind. J. Med. Res., 66(3): 440-448.

Diab, A.S.; EL-Nagar,O.G. and Abd-El-Hady, M.Y. (2002). Evaluation of Nigella sativa L. (black seeds; baraka), Allium sativum (garlic) and Biogen as a feed additives on growth performance of Oreochromis niloticus fingerlings, Vet. Med., J., Suez Canal University, 2: 745-753.

Drago 1, Mombelli B, De Vecchi E, Fassina MC, Tocalli L and Gismondo MR. (2000). Invitro antimicrobial activity of propolis dry extract. J. Chemoth., 12:390-411.

Duncan, D.B. (1955). "Multiple range test and multiple F tests." Biometrics, 11 (1): 1-42.

Eid, A.H. and Khalid, A.M. (2008). Effect of using probiotic as growth promoters in commercial diets for monosex Nile tilapia (Oreochromis niloticus) fingerlings. The eighth International Symposium on tilapia in Aquacult., 1: 241-253.

El-Hammady (2001). "Nutritive values of corn Gluten meal and sesame seed meal in feed for hybrid tilapia (Oreochromis niloticus X Oreochromis aureus)." Egypt. J. Nutrit. Feed, 4 (1): 47- 66.

GAFRD "Gernal Authority for Fish Resources Development" (2012). Statistical analysis of total aquaculture production in Egypt. Ministry of Agriculture, Cairo, Egypt. [Arabic Ed.].

Guobin Zhang, Shiyuan Gong, Denghang Yu and Hanwen Yuan (2009). Propolis and Herba Epimedii extracts enhance the non-specific immune response and disease resistance of Chinese sucker, Myxocyprinus asiaticus. Fish \& Shellfish Immunol., 26: 467-472. 
Haroun, E.R.; Goda, A.M. and Chowalhurrg, M. K. (2006). Effect of dietary probiotic Biogen supplementation as a growth promoter on growth performance and feed utilization of Nile tilapia (O. niloticus). Aquacult. Rese., 27 (14): 1473-1480.

Houghton PJ, Woldemariam TZ, Davey W, Baser A and Lau C (1995). Quantitation of the pinocembrin content of propolis by densitometry and high performance liquid chromatography. Phytochemical Analysis, 6:207-10.

Ibrahem, M. D.; Fathi, M.; Mesalhy, S. and Abd El-Aty, A. M. (2010). Effect of dietary supplementation of insulin and vitamin $\mathrm{C}$ on the growth, haematology, innate immunity, and resistance of Nile tilapia (Oreochromis niloticus). Fish \& Shellfish Immunol., 29:241- 256.

Ibrahem, M. D. (2013). Evolution of probiotics in aquatic world: Potential effects, the current status in Egypt and recent prospectives. J. of Advanced Res., Cairo University. Artical Rev.

Islam, K.M.S.; Schumacher, A.; Gropp, J. M. (2005). Humic Acid Substances in Animal Agricult. Pakis. J. Nutrit., 4 (3): 126-134.

Jobling, M. (1983). "A short review and critique of methodology used in fish growth and nutrition studies." J. Fish Biol., 23: 685-703.

Kosalec I, Bakmaz M, Pepeljnjak S. (2003). Analysis of propolis from the continental and Adriati regions of Croatia. Acta Pharmaceutica., 53:275-85.

Kraikruan, W.; Sangchote, S. and Sukprakarn, S. (2008). Effect of capsaicin on germination of Colletotrichum capsici conidia. Kasetsart J. (Nat. Sci.), 42: 417- 422.

Krell R. (1996). Value added products from beekeeping: Chapter 5: propolis. FAO Agric Serv Bull, 124.

Kumar, B.S.; Vijaysarathi, S.K. and Rao S. (2003). Effect of feeding probiotics on the performance of broilers in experimental fowl typhoid. Ind. Vet. J., 80: 52-55.

Lara-Flores, M.; Olvera, B.; Guzman, E. and Lopez, W. (2003). Use of bacteria Streptococcus faecium and lactobacillus, and the yeast Saccharomyces cereviae as growth promoters in the Nile tilapia. Aquacult., 216:193-201.

Levic J., Sinisa M., Djuragic O. and Slavica S. (2008). Herbs and organic acids as an alternative for antibiotic- growth-promoters. Archiva Zootechnica, 11: 5-11.

Mahmoud F. Salem (2010). Evaluation of (Bio-Nutra 200) as A Commercial Probiotic Product in Nile Tilapia (Oreochromis niloticus) Diets. J. of the Arabian Aquacult. Soci., 5 (1): 1-18.

Miyake T. and Shibamoto T. (1997). Antioxidative activities of natural compounds found in plants. J. of Agriculture and Food Chem., 45:1819-22.

Nopanitaya W (1973). Long term effects of capsaicin on fat absorption and growth of the rat. Growth, 37: 269-279.

Osman Tolga (2012). humic substances usage in aquaculture facilities. A Review, SAE J. of Arts and Sciences, 1: 519-527.

Panigrahi, A. and Azad, I. S. (2007). Microbial intervention for better fish health in aquaculture: the Indian scenario. Fish Physiol. Biochem., 33:429-40.

Ringo, E. and Gatesoupe, J. (1998). Lactic acid bacteria in fish. a Rev. Aquacult., 160: 177-203.

Scholz, U.; GarciaDiaz, D.; Ricque, L. and Latchford, J. (1999). Enhancement of Vibriosis resistance in juvenile Penaeus vannamal by supplementation of diets with different yeast products. Aquacult., 176: 271-283.

Schweiggert, U.; Kurz, C. and Schieber, A. (2007). Effects of processing and storage on the stability of free and esterified carotenoids of red peppers (Capsicum annum L.) and hot chilli peppers (Capsicum frutescens L.). Eur. Food Res. Technol., 225:261-270.

Sevdan Y1lmaz, Sebahattin Ergün and Nergiz Soytaş (2013). Dietary supplementation of cumin (Cuminum cyminum) preventing streptococcal disease during first-feeding of Mozambique tilapia (Oreochromis mossambicus). J. Bio. Sci. Biotech., 2(2):117-124.

Sforcin JM. (2007). Propolis and the immune system: a Revi. J. Ethnophar., 113: 1-14. 
Singh, T. and Chittenden, C. (2008). In-vitro antifungal activity of chilli extracts in combination with Lactobacillus casei against common sapstain fungi. Int. Biodeter. Biodegr., 62: 364-367.

SPSS Inc. (Released 2008). SPSS Statistics for Windows, Version 17.0. Chicago: SPSS Inc, USA.

Suzuki T. and Iwai K. (1984). Constituents of red pepper spices: Chemistry, Biochemistry, Pharmacology and food science of the pungent principle of capsicum species. In: BioSci A (Ed.). The Alkaloids. New York. Acad. Press, 23: 227-299.

Tewksbury, J.J.; Reagan, K.M.; Machnicki, N.J.; Carlo, T.A.; Haak, D.C.; Peñaloza, A.L.C. and Levey, D.J. (2008). Evolutionary ecology of pungency in wild chillies. PNAS 105: 11808-11811.

Turan F. (2006). Improvement of growth performance in Tilapia (Oreochromis niloticus Linnaeus) by supplementation of red clover (Trifolium pretense) in diets. Bamidgeh, 58: 34-38.

Wassef, E.A.; Stavros, C.; Sakr E.M. And Saleh N.E. (2010). Effect of Two Natural Carotenoid Sources in Diets for Gilthead Seabream, Sparus aurata on Growth and Skin Coloration. J. Appl. Aquacult., 22:216-229.

Wray, C. and Davies R.H. (2000). Competitive exclusion-an alternative to antibiotics. Vet. J., 159: 107-108.

Yilmaz E., Genc M.A., Cek S., Mazlum Y. and Genc E. (2006). Effects of orally administered Ferula coskunii (Apiaceae) on growth, body composition and histology of common carp, Cyprinus carpio. J. Anim. Vet. Adv., 5: 1236-1238.

Zakes Z., Kowalska A., Demska-Zakes K., Jeney G. and Jeney Z. (2008). Effect of two medicinal herbs (Astragalus radix and Lonicera japonica) on the growth performance and body composition of juvenile pike perch (Sander lucioperca). Aquacult. res., 39:1149-1160.

\section{ARABIC SUMMARY}

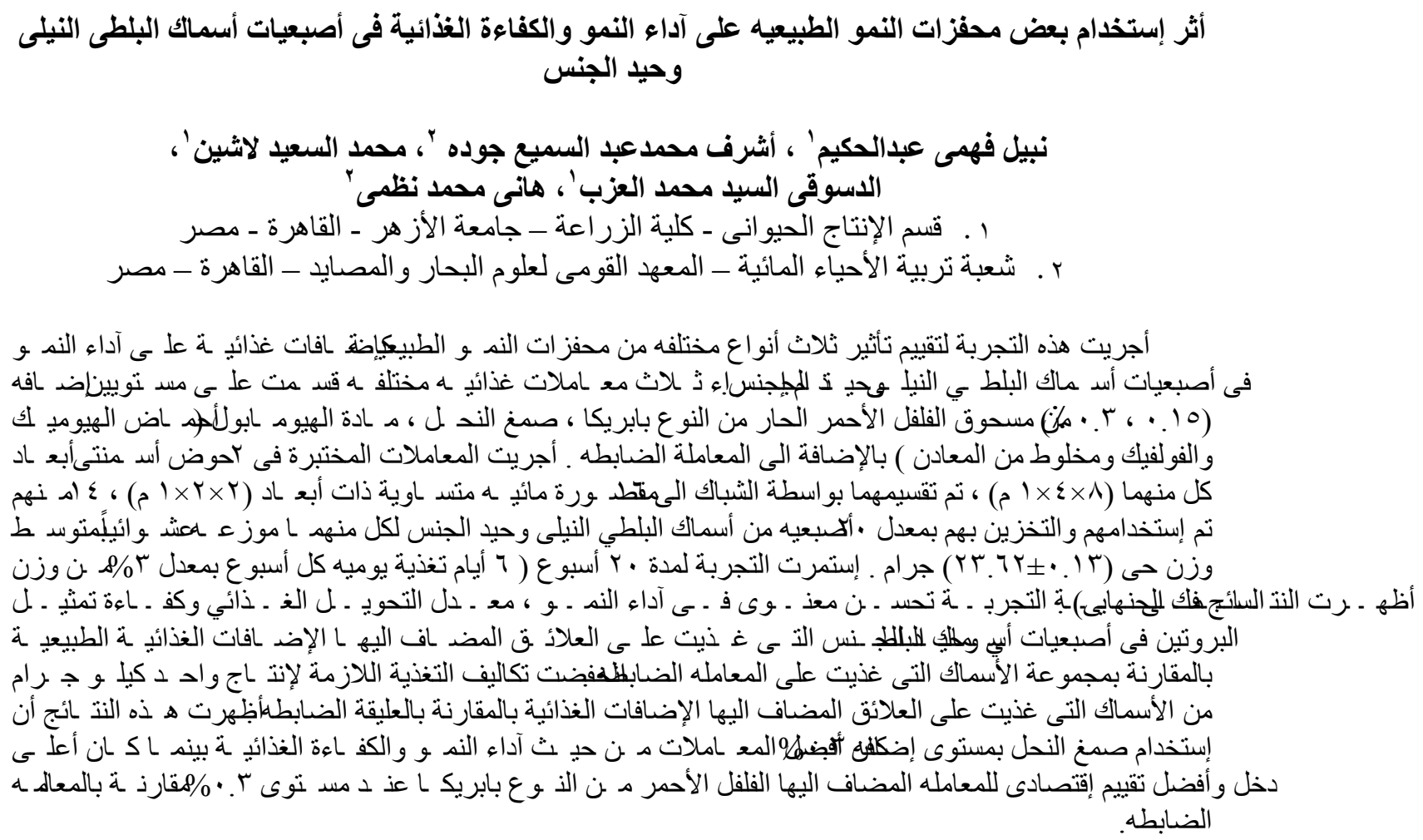

